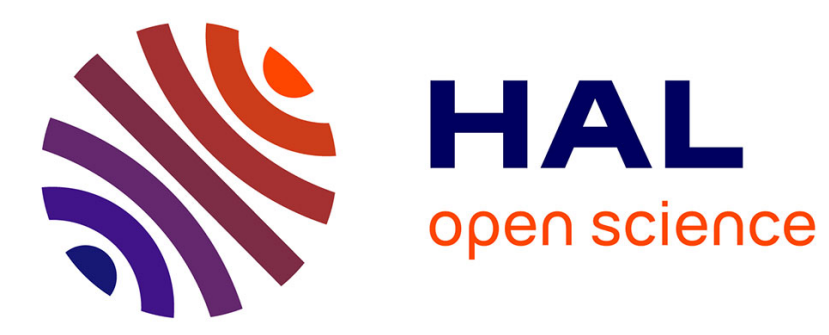

\title{
Maps of animal urban agriculture in Kampala City
}

Allan Komakech, Noble Banadda, Girma Gebresenbet, Björn Vinnerås

\section{To cite this version:}

Allan Komakech, Noble Banadda, Girma Gebresenbet, Björn Vinnerås. Maps of animal urban agriculture in Kampala City. Agronomy for Sustainable Development, 2014, 34 (2), pp.493-500. 10.1007/s13593-013-0164-7 . hal-01234788

\section{HAL Id: hal-01234788 \\ https://hal.science/hal-01234788}

Submitted on 27 Nov 2015

HAL is a multi-disciplinary open access archive for the deposit and dissemination of scientific research documents, whether they are published or not. The documents may come from teaching and research institutions in France or abroad, or from public or private research centers.
L'archive ouverte pluridisciplinaire HAL, est destinée au dépôt et à la diffusion de documents scientifiques de niveau recherche, publiés ou non, émanant des établissements d'enseignement et de recherche français ou étrangers, des laboratoires publics ou privés. 


\title{
Maps of animal urban agriculture in Kampala City
}

\author{
Allan John Komakech • Noble Ephraim Banadda • \\ Girma Gebresenbet • Björn Vinnerås
}

Accepted: 18 June 2013 / Published online: 12 July 2013

(C) INRA and Springer-Verlag France 2013

\begin{abstract}
Animal urban agriculture has a vital role to feed the ever-growing population of African cities. However, there is a lack of knowledge on animal farming, animal feed and manure recycling in cities. Here, we mapped animal farms in Kampala City. We determined the number and type of animals kept. We identified animal feeds and the manure management practices. The results show that animal farms are predominantly located on the periphery of the city. Poultry are the dominant animal species in the city, followed by pigs, cattle, goats and sheep. The most common feedstuffs are fruit and vegetable peel and pasture. Sixty percent of the animal manure is discarded, whereas $32 \%$ is recycled as fertiliser. Therefore, the fertiliser potential of manure is underutilised.
\end{abstract}

Keywords Animal farms $\cdot$ Feeds $\cdot$ Fertiliser $\cdot$ Manure management

\section{Introduction}

There is an ever-increasing pressure on the livestock sector to meet the growing demand for high-value animal protein in many parts of the world, and therefore, the global livestock sector is growing at an unprecedented rate. The driving force behind this enormous surge is a combination of population growth, rising income and urbanisation. According to Alberti (2010), most of the global population growth in the next 20years will be concentrated in urban areas in low and middle income countries, as a result of rural dwellers moving to urban areas (Deelstra and Girardet 2000; Satterthwaite 2009). As the

\footnotetext{
A. J. Komakech · G. Gebresenbet • B. Vinnerås

Energy and Technology Department, Swedish University of

Agricultural Sciences, P.O. Box 7032, 75007 Uppsala, Sweden
}

\section{A. J. Komakech $(\square) \cdot$ N. E. Banadda}

Agricultural and Bio-systems Engineering Department, College of

Agricultural and Environmental Sciences, Makerere University,

P.O. Box 7062, Kampala, Uganda

e-mail: allankoma@gmail.com population of these urban areas continues to grow, extra resources will be required to feed it. At present, most of this food requirement is met by a variety of sources, but these are becoming more unreliable for various reasons, e.g. natural hazards and climate change (Nugent 2000; Zezza and Tasciotti 2010). Promotion of urban agriculture can sustain the growth of cities, as it can provide a good buffer against any disruption in the normal food supply sector (Nugent 2000; Zezza and Tasciotti 2010). In addition, at household level, urban agriculture is a source of income and improves the health status of the household through provision of nutritious foods such as vegetables, fruits and animal protein (Zezza and Tasciotti 2010; Gillah et al. 2012).

According to Maxwell (1995), urban agriculture in Kampala City, Uganda, has two origins. The first of these was the expansion of the city boundaries in 1968, which had the effect of bringing into the city environs peri-urban areas where farming was the main occupation. Farming has continued to be practised in these areas, albeit at a level that is gradually declining. The second origin is the socio-political changes that took place in Uganda in the mid-1970s. These changes had a negative outcome in that they impoverished many of the city's inhabitants by eroding the value of their salaries and wages. Thus, to stabilise household food security and prevent malnutrition in their families, these households had to engage in urban agriculture.

On average, over $35 \%$ of the households in sub-Saharan African cities, including Kampala, currently engage in some form of urban agriculture. Of these, an average of $13 \%$ is engaged in livestock production (Fig. 1) and $36 \%$ in crop production (Zezza and Tasciotti 2010). However, in Kampala, the latter has been significantly affected by soil degradation, leading to reduced yields. This is because nutrients lost from the field each season through crop harvests are not replaced (Mubiru et al. 2007). A remedy to this problem is to encourage the use of animal manure on crop farms. However, for this to be feasible, it is important to know the location of animal farms, the type and number of animals available on these farms and the manure management system used. It is also important to identify the feeds being used to feed the animals 
Fig. 1 Animal urban agriculture in Kampala

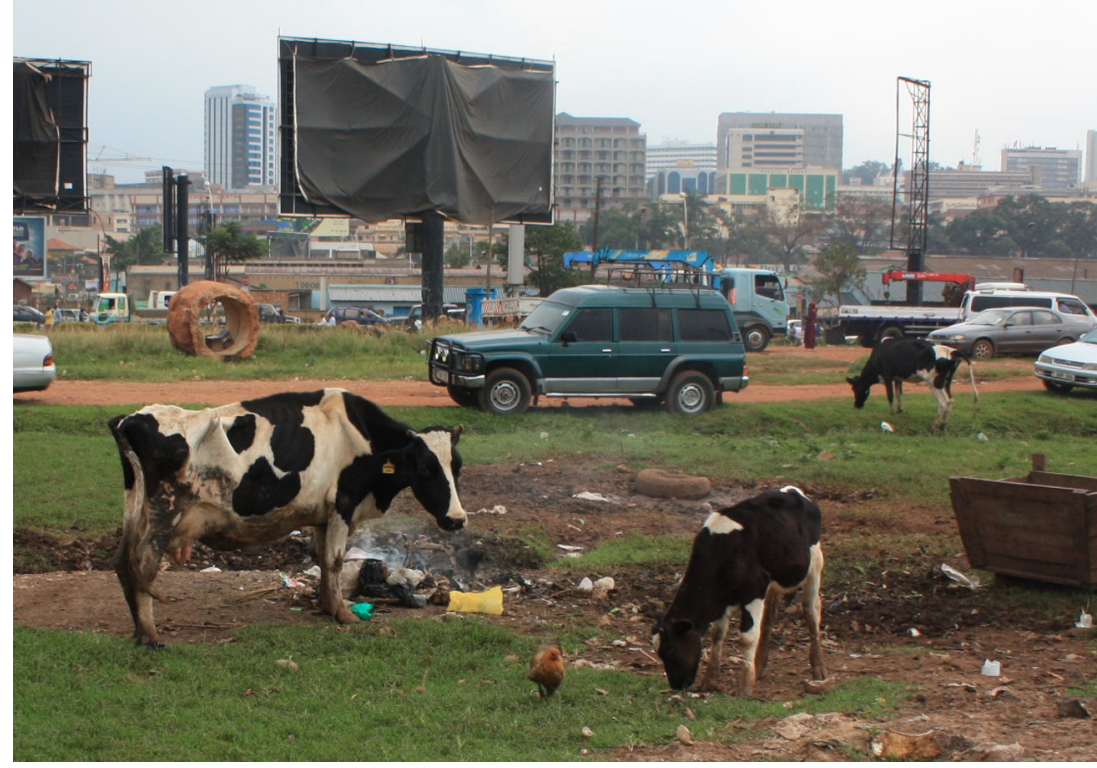

because this will determine the nutrient content of the manure (Mubiru et al. 2007). Although various researchers have conducted studies in Kampala City to establish the number of animals and the type of animal feeds used (UBOS 2008; Katongole et al. 2011), these studies are unreliable since the sample size was small. Furthermore, although other related studies (Nyombi et al. 2006; Mubiru et al. 2007; Zake et al. 2010) have been conducted on manure management in Uganda, they have not examined Kampala City and have only focused on manure as a fertiliser.

Urban animal farms play an important part in organic waste management, as a large proportion of the feed originates from household, market and food industry waste products. However, many of the plant nutrients and organic substances remain after passage through the animal and can still result in environmental pollution. In addition, if the manure is not managed properly, there is a risk of disease transmission to other animals and to humans in the case of zoonotic diseases (Albihn and Vinneras 2007). With proper manure management, this environmental pollution source can be turned into a valuable resource.

The objectives of the present study were thus to: (a) map animal farms, (b) identify the feeds used for the animals and (c) determine manure generation and management in the different divisions of Kampala City.

\section{Materials and methods}

\subsection{Study area}

The study was conducted in Kampala City, Uganda's capital, which is situated at $0^{\circ} 15^{\prime} \mathrm{N}, 32^{\circ} 30^{\prime} \mathrm{E}$ (Okalebo et al. 2010). Kampala City is also Uganda's administrative, political, commercial, industrial and educational centre (Banadda et al. 2009). The city covers an area of $195 \mathrm{~km}^{2}$ and is situated on the northern shores of Lake Victoria, at an altitude of 1,180 masl (Okalebo et al. 2010). It receives mean annual rainfall of 1,200 mm (Matagi 2002).

In administrative terms, Kampala City is subdivided into five divisions: Rubaga, Kawempe, Nakawa, Makindye and Central. Nakawa and Makindye are the largest divisions, covering 46.5 and $40.7 \mathrm{~km}^{2}$, respectively. Central division is the smallest, with an area of $14.7 \mathrm{~km}^{2}$ (MFPED 2000). Land ownership in Kampala district falls into one of five categories: private land (normally referred to as mailo) (49\%); statutory leases held by Kampala Capital City Authority (KCCA) (30\%); land under the direct control of Uganda Land Commission (ULC) for government development projects (10\%); freehold (7\%); and leases held by institutions (4\%). As regards the relative distribution of the various tenure systems in the five divisions, more than $90 \%$ of the landholdings in Kawempe, Rubaga and Makindye divisions are mailo, while in Nakawa and Central divisions, the predominant tenure system (80 \%) is leasehold from KCCA and ULC (MFPED 2000; Giddings 2009).

Kampala City has numerous streams and wetlands. The latter cover approximately $16 \%$ of the area and most are permanently water-logged, mainly due to impeded drainage but also due to prevalent year-round rainfall (MFPED 2000; Okalebo et al. 2010).

\subsection{Data collection}

This study was conducted between March and August 2011, mainly among households involved in animal production in and around Kampala City. These households were identified and contacted with the help of their respective veterinary 
assistant. The veterinary assistants are known to the animal farmers, as they are in regular contact with them in provision of various services such as treatment of diseases, vaccination and artificial insemination. A total of 1,300 animal farmers from in and around Kampala City were interviewed.

Data collected from the different farming households included the global positioning system (GPS) coordinates of the farm (obtained using a Magellan Triton 500 hand-held GPS instrument), the type and number of animals kept, the type and origin of the animal feed used and the current usage of manure generated by the animals.

\subsection{Data analysis}

The data were analysed using descriptive statistics in Microsoft Excel and were found to show a normal distribution. The data were also analysed using $\mathrm{R}$ software for statistical analysis of variance (ANOVA), Tukey test and logistic regression (Venables et al. 2012). The location of the farms was mapped using the Geographic Information System ArcMap 10 software, following the procedure specified by Hillier (2011).

\section{Results and discussions}

\subsection{Farms in Kampala}

There are some major differences in the number of farms within the five divisions of Kampala City (Table 1). There are far fewer farms in Central division than in the other divisions, while Rubaga division has the largest number of farms. Nakawa, on the other hand, has the largest number of animal units. It is interesting to note that Rubaga division has the lowest number of animal units per farm, which can be attributed to the small-scale nature of most farms in that division.

The areas on the periphery, where most of the animal farms are found, are more peri-urban in nature and have a lower population density than more central areas. This means that there is more land available for practising urban agriculture in general and livestock rearing in particular. In addition, affluent residential suburbs are located in places (Central and Nakawa divisions) that appear devoid of animal farms (Fig. 2). The residents of these divisions do not necessarily need to supplement their income with farming activities. This confirms findings by Zezza and Tasciotti (2010) that it is mainly poorer households that engage in urban agriculture in developing countries. However, another explanation is the expansion of Kampala City boundaries in 1968 to include neighbouring peri-urban areas where farming was the main occupation (Maxwell 1995). Although the intensity of farming, especially animal rearing, has decreased since then, it nevertheless continues to be practised, as shown by the high number of animal farms still found in these areas (Fig. 2).

Poultry were the most numerous animal kept in all divisions, followed by pigs, cattle, goats and sheep in that order (Table 1). ANOVA tests showed no significant difference in the number of sheep, cattle and pigs in the different divisions $(P>0.05)$. However, there was a significant difference in the poultry population in the different divisions $(P<0.001)$.

Kawempe and Rubaga divisions, where most animal farms are located (Fig. 2), are the poorest in terms of per capita income, house many of the urban poor and border on districts that are peri-urban. It is thus logical for these urban poor dwellers to supplement their earnings through urban agriculture. In addition, the predominant land tenure in these two divisions is private land (mailo), which according to Giddings (2009) is unregulated by KCCA and thus occupied haphazardly by migrants to the area. Although the Physical Planning Act of 2010 makes KCCA responsible for planning and regulating land use in Kampala, it has not yet carried out this role fully in the city, especially on mailo land. Thus at the moment, it applies its planning and regulating function only

Table 1 Number of animals and farms in the five divisions of Kampala City, Uganda

\begin{tabular}{|c|c|c|c|c|c|c|c|c|c|c|c|c|}
\hline \multirow[t]{2}{*}{ Name of division } & \multirow[t]{2}{*}{ No. of farms } & \multicolumn{2}{|c|}{ No. of sheep } & \multicolumn{2}{|c|}{ No. of goats } & \multicolumn{2}{|c|}{ No. of cattle } & \multicolumn{2}{|c|}{ No. of pigs } & \multicolumn{2}{|c|}{ No. of poultry } & \multirow[t]{2}{*}{ Animal units ${ }^{\mathrm{a}}$} \\
\hline & & A & $\mathrm{F}$ & A & $\mathrm{F}$ & A & $\mathrm{F}$ & A & $\mathrm{F}$ & A & $\mathrm{F}$ & \\
\hline Central & 22 & 19 & 4 & 53 & 9 & 62 & 14 & 51 & 3 & 299 & 6 & 63 \\
\hline Kawempe & 450 & 96 & 24 & 960 & 128 & 1,630 & 296 & 1,200 & 107 & 75,400 & 176 & 1,900 \\
\hline Makindye & 120 & 19 & 8 & 500 & 50 & 610 & 97 & 740 & 33 & 11,900 & 57 & 590 \\
\hline Nakawa & 200 & 21 & 6 & 480 & 71 & 620 & 86 & 5,800 & 48 & 113,000 & 45 & 2,100 \\
\hline Rubaga & 510 & 57 & 21 & 1,100 & 199 & 930 & 185 & 1,200 & 150 & 47,300 & 57 & 1,300 \\
\hline Total & 1,296 & 212 & & 3,076 & & 3,849 & & 9,007 & & 247,454 & & \\
\hline Animal units ${ }^{\mathrm{a}}$ & & 21 & & 310 & & 2,200 & & 900 & & 2,500 & & 5,950 \\
\hline
\end{tabular}

$A$ animals, $F$ farms

${ }^{\text {a }}$ One animal unit is equal to one dairy cow or three other cattle or ten sheep, goats and fattening pigs or 100 poultry 


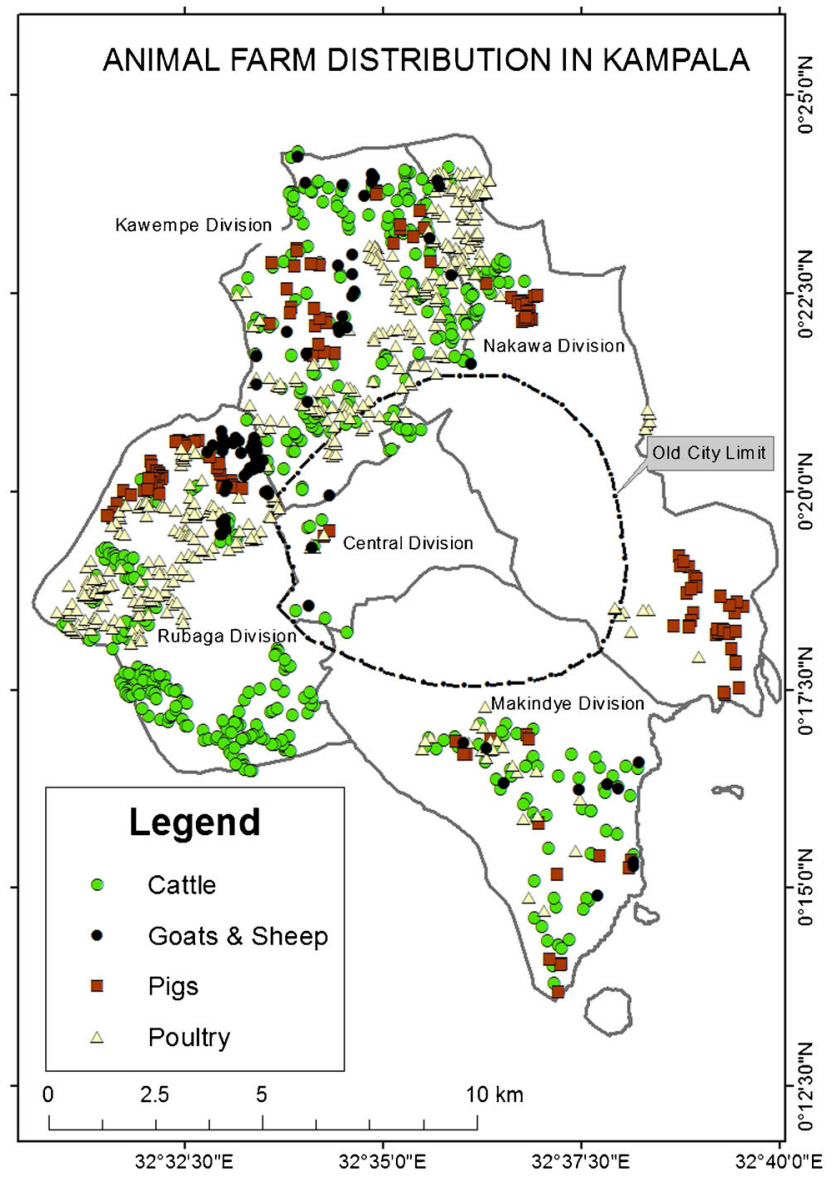

Fig. 2 Animal farm distribution in the five divisions of Kampala

to those with title to their land and even then only when these individuals approach the KCCA central planning office. All the other inhabitants have to do is to obtain the consent of the village local council chief and a verbal no objection from KCCA officials at the divisions, and then, they can use their land as they wish (Muinde 2013). Furthermore, the first places in Kampala that most rural migrants arrive at on entering Kampala City are Kawempe (migrants from northern, mid-western and eastern Uganda) and Rubaga (migrants from western, southern and central Uganda). Most of these migrants are of weak financial standing and come to the city to look for employment. Government policies are silent on the problem of migrants and therefore they do not attract any institutional support such as regulation and financial incentives. Thus, they have to fend for themselves. Some of them, with the consent of their hosts/landlords, gradually resort to animal production. They do so as a way to cut their costs, improve their nutritional status and create a source of income (Nakiganda et al. 2006). Similar findings have been reported for Kisumu City, Kenya (Mireri et al. 2007). It is also likely that some migrants are involved in animal production as part of their culture and as a hobby, as suggested by Katongole et al. (2011). On the other hand, the predominant land tenure form in Central and Nakawa divisions is leasehold from KCCA and ULC (MFPED 2000). During colonial rule, this land was administered directly by the colonial authorities (Okalebo et al. 2010; Muinde 2013) and was thus developed in a fairly orderly and planned manner. Much of the land in Central and Nakawa divisions is where the British administrators and other Europeans and Asians lived during colonial times and is thus relatively well planned and serviced, with not much space for rearing animals.

The dominant animal category kept in Kampala was found to be poultry, followed by pigs (Table 1). In contrast, Katongole et al. (2011) and Prain et al. (2010) reported higher numbers of cattle than pigs in the city. This difference is probably due to differences in sample size, as the former authors based their results on only 125 farms and the latter on only 175 farms, while the present study included 1,300 farms and had the intention of including all urban farms in Kampala City. We found more cattle than goats and sheep combined (Table 1), a finding similar to that reported by Katongole et al. (2011). A reason for this could be the higher milk-producing ability of cattle, which continuously generates both income and food for the household. The results obtained for Kampala are similar to those reported for Dar es Salaam, Tanzania but different from those reported for Nairobi, Kenya (DFID 2002). For the latter, the most common livestock type was found to be goats, followed by poultry, cattle and sheep. Pigs were rarely found in Nairobi (DFID 2002).

The number of poultry was significantly $(P<0.001)$ higher in Nakawa than in the other divisions (Table 1). This is explained by the presence of large-scale chicken farms in Nakawa division, where the average flock consists of 2,500 birds, while the other divisions have 300 birds per farm. However, both these figures are far above the national average of 12 chickens per household (UBOS 2008), mainly because most poultry farmers in Kampala are commercial farmers (Prain et al. 2010).

The national livestock census for Uganda (UBOS 2008) reported that Kampala district has approximately 32,000 cattle, 64,000 goats, 8,800 sheep, 38,300 pigs and 1,053,000 poultry. This is five to ten times higher than the numbers found in this study (Table 1). A possible reason for this discrepancy is differences in the methodology used. The livestock census used the agricultural sample survey method, where animals in $15.1 \%$ of the households in Kampala were counted and the figures were extrapolated to give the total number of animals (UBOS 2008). However, the distribution of animal farms in Kampala City is very uneven (Fig. 2), which can result in great bias in animal counts when using this method. In addition, the number of urban animal farmers in Kampala has decreased lately, as animal rearing in the city was banned in connection with establishment of KCCA and animals found roaming in the city have been impounded 
(Kajoba 2012). This could also explain the higher population of pigs compared with cattle than in earlier studies, since pigs are normally confined, whereas cattle generally graze freely and are thus more likely to be impounded by the municipal authorities. Another reason for the discrepancy could be the increase in costs, especially those of commercial feeds, at the time of the present study (Nantaba 2011). This has led a number of farmers, especially commercial chicken farmers, to abandon farming due to lack of profitability.

\subsection{Animal feed sources in Kampala}

The animals in Kampala City were found to be fed a variety of feeds, including peel (banana, potatoes and cassava) (62\%), food waste ( $22 \%$ ), pasture (elephant grass, assorted grass, free range and tethering) (82\%), commercial feeds including bran and mixed feeds (37\%), brewery waste $(10 \%)$, dregs (2\%), market waste $(9 \%)$ and crop residues $(11 \%)$. This is in agreement with previous studies (Maxwell 1995; Ishagi et al. 2002; Katongole et al. 2011), which pointed out the importance of different animal feeds complementing each other. A similar finding for Kampala City was reported by Prain et al. (2010). Likewise in Nakuru, Kenya, a variety of animal feeds are used, including pasture (53\%), concentrates (30\%) and organic refuse (17\%) (Prain et al. 2010).

Most of the local/indigenous cattle breeds kept in Kampala are predominantly communally grazed (free range) $(P<0.001$, odds ratio $(\mathrm{OR})=1.1)$, although in some instances, they are tethered on pasture $(P>0.05)$. The exotic or improved cattle breeds are mainly kept under zero grazing, although a few are also tethered on pasture. Most of the goats and sheep are either left to roam freely or tethered $(P<0.001, \mathrm{OR}=1.2)$, although a few are also kept under zero grazing $(P>0.05)$. These findings are similar to those reported by Ishagi et al. (2002). Cattle are fed mainly on pasture forage (assorted or elephant grass) $(P<0.001, \mathrm{OR}=1.1)$, peel $(P<0.001, \mathrm{OR}=1.1)$ and in some instances market wastes and crop wastes $(P>0.05)$. Dairy cattle are also fed on spent yeast from breweries (brewery waste). Goats and sheep are fed mainly on peel $(P<0.001$, $\mathrm{OR}=1.2)$, market waste $(P<0.01, \mathrm{OR}=1.1)$ and pasture $(P<0.05, \mathrm{OR}=1.0)$; pigs mainly on food waste and bran $(P<0.001, \mathrm{OR}=1.3)$ and dregs when available $(P>0.05)$; and poultry mainly on commercial feed $(P<0.001, \mathrm{OR}=1.1)$ and to a lesser extent on mixed feeds $(P>0.05)$.

Sources of food waste include neighbours and the farm household (free of charge as a waste disposal service), as well as hotels, markets and in rare instances schools (food waste mostly has to be purchased from these places). Elephant/assorted grass is normally bought from vendors, harvested from the farm grass gardens or gathered from among the grass growing wild in various places, but mainly in the wetlands. It is very common to find pasture-gathering teams or groups along fallow land, open grassland and greens in and around Kampala City. Where paddocks exist, animals feed on the assorted grasses there. Other animal feeds have single sources and these include waste obtained from the markets, bran and commercial and mixed feeds bought from animal feed traders. Dregs, a by-product of the local brewery, are obtained free of charge from the community. Brewery waste is bought from the Uganda breweries plant at Luzira, and crop residues are obtained free of charge from either the farm or the neighbours' crop fields.

It should also be noted that several farmers who obtained peel free as a waste disposal service complained about the material being highly contaminated with plastics, glass and other waste fractions that are dangerous to animals. This could be due to households viewing their peel collection containers as waste containers in which all sorts of waste can be dumped. Farmers therefore first have to sort the waste before feeding it to the animals. The same applies to peel obtained from the markets.

The use of feeds such as market and food wastes is good from a sustainability point of view, as it means that nutrients which would otherwise be lost can be captured and used for nutrient recycling in the form of animal manure (Zake et al. 2010). However, we did not determine the nutrient content of the different animal feeds and manures in this study.

\subsection{Animal waste management}

The animal waste produced in Kampala mainly consists of animal faeces (poultry droppings) and urine. Most of the animal manure generated in the city is discarded in some way $(60 \%)$ or is used as fertiliser on crop fields (32\%). Other ways in which the manure generated is utilised include donation free of charge to those that need it (3\%), especially peri-urban farm owners, selling it (2\%), taking it to the village to be used as fertiliser in the gardens there $(1 \%)$, generation of biogas $(1 \%)$ and incineration for insect control reasons $(1 \%)$. Other insignificant uses include construction, feed for pigs and just heaping it up and letting the rain wash it away. Many farmers discard the manure as there is no comprehensive national urban policy and institutional framework to regulate the use of solid waste in the country (WaterAid 2011). Of the farmers surveyed here that used the manure as fertiliser in their gardens, $70 \%$ preferred to store it in a heap/pit before application, while $30 \%$ applied it directly without any storage. Almost none of the farmers covered the manure during storage. The animal manure usage in this study is similar to that reported by Prain et al. (2010) for Nakuru City, Kenya, where $54.5 \%$ of the manure generated was discarded, $30.3 \%$ was used as fertiliser in crop fields, $1.3 \%$ was sold and $13.9 \%$ had different uses. In Yaoundé City, Cameroon, on the other hand, most of the manure generated is used as fertiliser on crop fields within the city, while about $10 \%$ is sold as fertiliser to other provinces. This has been attributed to the higher level of 
awareness among urban farmers in Yaoundé of the contribution of manure to soil fertility (Prain et al. 2010).

Nakawa division, which has the largest number of animal units, especially large-scale poultry and pig farms (Table 1), generates the largest quantity of manure in Kampala City. The other divisions have considerably fewer animals per farm, with Makindye (five) Kawempe (four), Rubaga and Central (three) division ranking second, third and fourth, respectively, in generation of animal manure per farm.

Most of the manure in Kampala City, especially in Central, Rubaga, Kawempe and Nakawa divisions, is discarded. According to Zake et al. (2010), this is because the smallholder farmers attach little importance to manure management. The urban crop-producing farms also ignore the resources in the manure, resulting in soil degradation and reduced crop yields (Mubiru et al. 2007). Most of the discarded manure is dumped into drainage channels, where it is carried off by running water. In the few areas that have KCCA skips nearby, some manure is dumped in them and is eventually disposed of in the city landfill. Some manure is heaped and left uncovered, which not only leads to contamination of the atmosphere with greenhouse gases, but also leaves the manure exposed to disease vectors such as flies and to runoff by rain events. Through the running water, the manure eventually finds its way to Lake Victoria, hence contributing to its eutrophication (Banadda et al. 2009). In the past, the numerous natural wetlands around Kampala acted as filters for the polluted water, but most of these have been destroyed as a result of human activities. Eutrophication has not only resulted in loss in biodiversity of Lake Victoria, but has also led to a significant increase in water treatment costs for the National Water and Sewage Corporation, the body charged with treating and supplying clean water to Kampala City (Banadda et al. 2009).

Around one third of the manure generated in Kampala is used as fertiliser. This is especially true for the divisions of Makindye, Nakawa and Kawempe (Fig. 3). A reason for this is the ownership of fairly large pieces of land by urban farmers in these divisions, thus enabling them to practise both animal and crop production. In this case, the manure generated by their animals is used as fertiliser on their own land, as animal manure is a cheap source of nutrients and can be used for soil fertility management on farms (Mubiru et al. 2007). Similar observations have been made for other East African urban areas, including Nakuru, Kenya (Prain et al. 2010) and Morogoro, Tanzania (Lupindu et al. 2012). No animal manure is used as fertiliser in Central division of Kampala due to fact that the area is heavily built-up, with little empty space for crop production. Some animal manure is sold, donated or taken to the villages. This practice, which is common in the divisions of Makindye, Central and Kawempe, is found if the urban livestock farmers either do not engage in crop

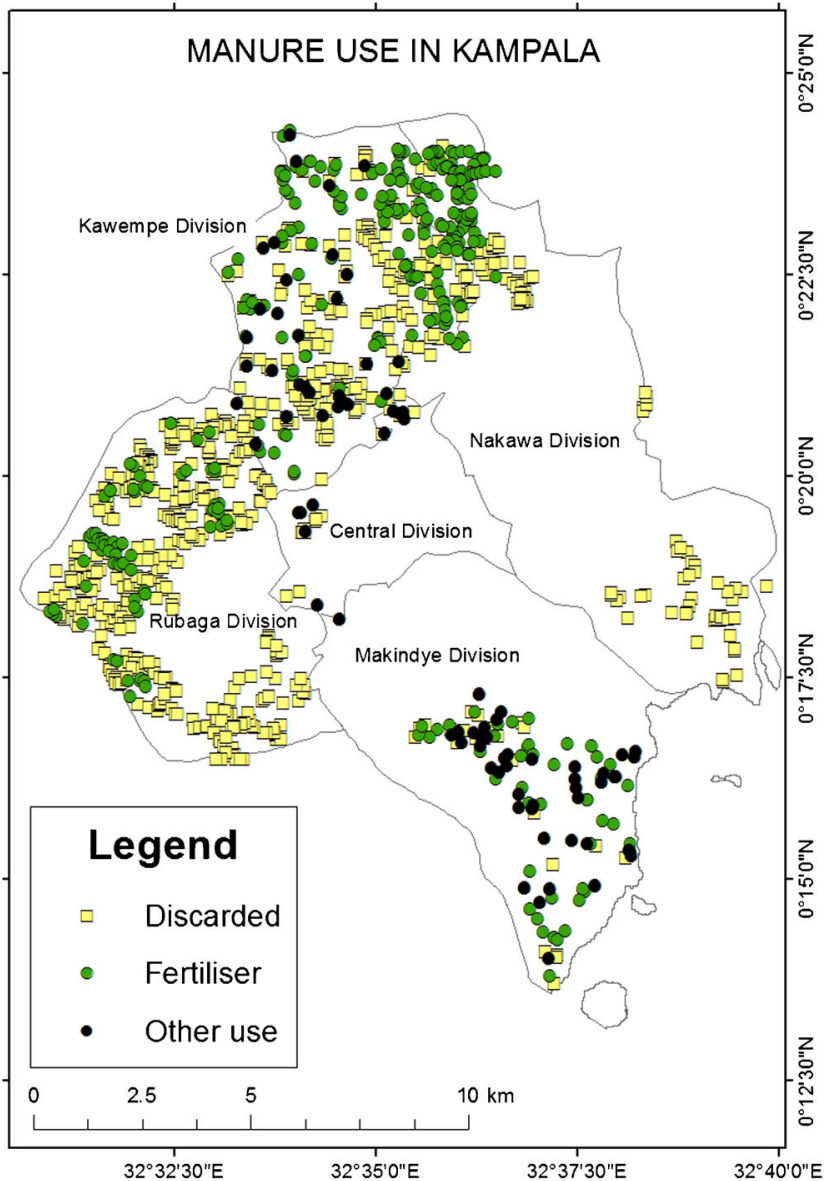

Fig. 3 Manure management in the five divisions of Kampala

production or have gardens too small to accommodate the manure generated. In this case, where the demand for the manure is high, they sell it off. Otherwise, they donate it to those with gardens. Some animal manure is also used for energy generation (burning/incineration and biogas).

Although this study did not identify the manure management systems used in the different divisions, proper manure management is nevertheless a very important factor in conserving the nutrient value of the manure. Its optimal utilisation on the farm, through appropriate collection, handling and application in the field, would have a significant effect on nutrient availability to crops (Zake et al. 2010). However, for animal manure to be used as an effective fertiliser, highquality feed must be given to the animals, since they excrete $75 \%$ of the nitrogen, $80 \%$ of the phosphorus and $85 \%$ of the potassium they ingest in the feed (Mubiru et al. 2007; Zake et al. 2010).

\section{Conclusions}

Animal farms are predominantly located around the periphery of Kampala, mainly in Kawempe and Rubaga divisions. 
These are also the poorest divisions in Kampala City, showing the clear connection between urban animal agriculture and low income. Nakawa division has the largest number of animal units $(2,100)$, followed by Kawempe (1,900 units), Rubaga (1,300 units), Makindye (590 units) and Central (63 units). This study is the first to map the location of animal farms in the city and to determine the actual types and numbers of farm animals in the different divisions of the city. The farms are unevenly distributed in the city, so surveys that extrapolate the numbers of animals from a subsection up to the full city risk resulting in major inaccuracies regarding the number of animals in the city. A variety of feeds are used for feeding the animals in Kampala City, with the predominant feedstuffs being food peel and pasture. There is quite high potential for the use of manure as a fertiliser, since $>60 \%$ is currently wasted, mainly owing to lack of awareness among urban farmers and lack of sufficient regulation of manure disposal by the city authorities. However, the nutrient content of the major feeds used and the manure generated must be quantified and the hygiene quality of the manure determined in order to properly assess the quality of the resource currently available in Kampala. Larger farms often combine animal and crop production and tend to reuse manure more than small farms.

Acknowledgments The authors would like to express their sincere gratitude to the Swedish government through its agencies, namely the Foreign Affairs Ministry as part of its special allocation on global food security and the Swedish International Development Cooperation for fully funding this research. We would also like to thank Makerere University and Kampala Capital City Authority officials most especially Dr. Kwizera Herbert, who helped us to locate and interview the different animal farmers in Kampala.

\section{References}

Alberti M (2010) Maintaining ecological integrity and sustaining ecosystem function in urban areas. Curr Opin Environ Sustain 2(3):178184

Albihn A, Vinneras B (2007) Biosecurity and arable use of manure and biowaste - treatment alternatives. Livest Sci 112(3):232-239

Banadda E, Kansiime NF, Kigobe M, Kizza M, Nhapi I (2009) Landusebased nonpoint source pollution: a threat to water quality in Murchison Bay, Uganda. Water Policy 11(Supplement 1):93-104

Deelstra T, Girardet H (2000) Urban agriculture and sustainable cities. Growing cities, Growing food. Deutsche Stiftung für Entwicklung, Feldafing, pp 43-65

DFID (2002) Peri-urban and urban livestock keeping in East Africa-a copying strategy for the poor? Scoping study commissioned by the Livestock Production Programme (LPP) of the UK Department for International Development (DFID). http://r4d.dfid.gov.uk/PDF/ Outputs/ZC0201a.pdf. Accessed 28 May 2013

Giddings SW (2009) The land market in Kampala, Uganda and its effect on settlement patterns. International Housing Coalition. www.intlhc. org. Accessed 23 Oct 2012
Gillah KA, Kifaro GC, Madsen J (2012) Urban and peri urban dairy farming in East Africa: a review on production levels, constraints and opportunities. Livestock Research for Rural Development. 24(11): 198

Hillier A (2011) Manual for working with ArcGIS 10. School of Design. University of Pennsylvania. http://works.bepress.com/ smy hillier/24. Accessed 15 Oct 2012

Ishagi N, Ossiya S, Aliguma L, Aisu C (2002) Urban and peri-urban livestock keeping among the poor in Kampala city. Ibaren Konsultants, Kampala, Uganda. http://r4d.dfid.gov.uk/Output/64400/ Default.aspx. Accessed November 2012

Kajoba N (2012) KCCA impounds over 100 animals on city streets. New Vision newspaper, Kampala, Uganda. 29 August 2012

Katongole CB, Sabiiti E, Bareeba F, Ledin I (2011) Utilization of market crop wastes as animal feed in urban and peri-urban livestock production in Uganda. J Sustain Agric 35(3):329-342

Lupindu AM, Ngowi HA, Dalsgaard A, Olsen JE, Msoffe PLM (2012) Current manure management practices and hygiene aspects of urban and peri-urban livestock farming in Tanzania. Livestock Research for Rural Development. 24(9):167

Matagi SV (2002) Some issues of environmental concern in Kampala, the capital city of Uganda. Environ Monit Assess 77(2):121-138

Maxwell DG (1995) Alternative food security strategy: a household analysis of urban agriculture in Kampala. World Dev 23(10):16691681

MFPED (2000) Uganda participatory poverty assessment process. Kampala district report. Ministry of Finance, Planning and Economic Development (MFPED). The Republic of Uganda, 152

Mireri C, Atekyereza P, Kyessi A, Mushi N (2007) Environmental risks of urban agriculture in the Lake Victoria drainage basin: a case of Kisumu municipality, Kenya. Habitat Int 31(3-4):375386

Mubiru SL, Tenywa JS, Romney D, Halberg N (2007) Manure application as an option for improving nutrient balances, yields and income from major crop patterns in Uganda. 8th African Crop Science Society Conference, El-Minia, Egypt, 27-31 October 2007, pp. 1703-1707

Muinde DK (2013) Assessing the effects of land tenure on urban developments in Kampala. M.Sc. thesis. Faculty of Geo-Information Science and Earth Observation. University of Twente. http://www.itc. nl/library/papers_2013/msc/upm/muinde.pdf. Accessed 29 May 2013

Nakiganda A, McLeod A, Bua A, Phipps R, Upton M, Taylor N (2006) Farmers' constraints, objectives and achievements in smallholder dairy systems in Uganda. Livest Res Rural Dev 18(5):69

Nantaba E (2011) Feed prices threaten poultry farmers. East African Business Week. www.busiweek.com. Edition of 26th June 2011. Accessed 23 Oct 2012

Nugent R (2000) The impact of urban agriculture on the household and local economies. Growing cities, growing food: urban agriculture on the policy agenda, 67-97

Nyombi K, Esser KB, Zake JYK (2006) Efforts by small-scale farmers to maintain soil fertility and their impacts on soil properties, Luwero district, Uganda. J Sustain Agric 27(4):5-23

Okalebo OF, Haas T, Sengendo H (2010) Planning of Kampala city 1903-1962: the planning ideas, values and their physical expression. J Plan Hist 9(3):151-169

Prain G, Karanja N, Lee-Smith D (2010) African urban harvest. Agriculture in the cities of Cameroon. Kenya and Uganda, Springer, New York

Satterthwaite D (2009) The implications of population growth and urbanization for climate change. Environ Urban 21(2):545-567

UBOS (2008) The national livestock census: a summary report of the national livestock census, 2008. Uganda Bureau of Statistics (UBOS), Ministry of Finance, Planning and Economic Development, 
Kampala, Uganda. http://www.ubos.org/nada3/index.php/catalog/14. Accessed 10 Nov 2012

Venables WN, Smith DM, RC Team (2012) An introduction to R. Notes on R: a programming environment for data analysis and graphics. Version 2.15.1 (22-06-12)

WaterAid U (2011) Challenges of urban solid waste management in Kampala city. Issues for policy change. http://www.wateraid.org/ /
media/Publications/solid-waste-management-policy-brief-uganda. ashx. Accessed 1 June 2013

Zake J, Tenywa JS, Kabi F (2010) Improvement of manure management for crop production in central Uganda. J Sustain Agric 34(6):595-617

Zezza A, Tasciotti L (2010) Urban agriculture, poverty, and food security: empirical evidence from a sample of developing countries. Food Policy 35(4):265-273 